\title{
Synthesis, Spectroscopy, Thermal Analysis, Electrochemistry and Superoxide Scavenging Activity of a New Bimetallic Copper(II) Complex
}

\author{
Babita Sarma and Diganta Kumar Das \\ Department of Chemistry, Gauhati University, Assam, Guwahati 781 014, India \\ Correspondence should be addressed to Diganta Kumar Das; digantakdas@gmail.com
}

Received 25 June 2012; Revised 31 August 2012; Accepted 5 September 2012

Academic Editor: Andrea Trabocchi

Copyright (C) 2013 B. Sarma and D. K. Das. This is an open access article distributed under the Creative Commons Attribution License, which permits unrestricted use, distribution, and reproduction in any medium, provided the original work is properly cited.

A new bimetallic copper(II) complex has been synthesized with ligand obtained by the condensation of salicylaldehyde and the amine derived from reduction of nitration product of benzil. The ligand was characterized by ${ }^{1} \mathrm{H}$ NMR and mass spectra, and the binuclear Copper(II) complex was characterized by vibrational and electronic spectra, EPR spectra, and magnetic moment measurement. Thermogravimetric analysis study and electrochemical study of the complex were also done. The complex was found to show superoxide dismutase activity.

\section{Introduction}

Copper is a biologically important metal found in a number of enzymes such as-superoxide dismutase, tyrosinase, Bhydroxylases, monoaminooxidase, and ascorbic acid oxidase [1-3]. Complexes of copper in oxidation state +2 were found to show significant antioxidant and anti-free radical activity also $[4,5]$. Bimetallic copper complexes are potential models for a number of important biological systems containing couple sites [6] and have been studied extensively [7-12]. Bimetallic complexes of copper with Schiff bases have been shown to be useful chemical probe of DNA and have found its importance in various biochemical and biomedical applications [13, 14]. Synthesis of a new copper(II) complex with multidentate Schiff base ligand also contributes in the development of coordination chemistry [15-17].

Superoxide dismutase (SOD) is an enzyme which protects cells from the toxic effect of superoxide [18]. The three main types of SOD are- $\mathrm{Cu}-\mathrm{Zn}-\mathrm{SOD}, \mathrm{Mn}-\mathrm{SOD}$, and Fe-SOD of which the first one is found in mammals [19]. Deficiency or imbalance of SOD in human body leads to many diseases and disorders such as diabetes, ischemia, cataract, Parkinson's disease, and cancers $[20,21]$. Such disorders could be treated by supplementation of antioxidant enzymes but administration of these enzymes through oral or intraperitoneal routes is severely restricted due to their rapid degradation and short lifetime in biological systems [22]. Small metal complexes having good superoxide scavenging activity should be good candidate in this respect.

A good number of copper complexes have been reported to mimic SOD activity which includes copper(II) complexes with Schiff base ligands derived from various aldehydes and ketones [23], imidazole bridged copper(II) complexes [24], planar copper(II) complex on addition of a base such as $\mathrm{N}$ methyl imidazole or pyridine [25], curcumin complexes of copper(II) [26], and so forth. It is also reported that the copper(II) complexes with Schiff base ligands of salicylaldehyde semicarbazone have SOD activity which could be tuned by heterocyclic bases pyridine and $\mathrm{N}$-methyl imidazole [27]. There are recent reports on copper complexes with SOD activity having pyridine and pyrimidine derivatives [28-30].

In this paper, we report the synthesis of a new ligand by the condensation of salicylaldehyde and the amine derived from reduction of nitration product of benzil. The ligand was characterized by ${ }^{1} \mathrm{H}$ NMR and mass spectra. Binuclear copper (II) complex of the ligand was synthesized, and its FTIR 
spectra, electronic spectra, EPR spectra, thermogravimetric (TGA) analysis study, and electrochemical study results are reported.

\section{Experimental}

All the chemicals and solvents used for the synthesis are reagent grade. Benzil, ethylenediamine, and salicylaldehyde were purchased from Merck. The FTIR spectra were recorded using $\mathrm{KBr}$ discs on a Perkin-Elmer spectrum RXI FTIR system. The NMR spectra were recorded in Bruker Ultra shield 300 spectrophotometer. The electronic spectra in the range $200-1000 \mathrm{~nm}$ were obtained in acetonitrile on a UV1800 SHIMADZU spectrophotometer. Thermogravimetric measurements were carried out on a METTLER TOLEDO TGA/DSC instrument. Magnetic moment measurements were recorded at room temperature by the Gouys method using Cambridge Magnetic Balance. CHI 600B Electrochemical Analyzer (USA) with a three electrode cell assembly was used for electrochemical studies. The electrodes were cleaned as per reported procedure [31]. The SOD activity of the copper complex has been studied by the method of NBT reduction using $\mathrm{KO}_{2}{ }^{-\bullet}$ as the source of superoxide radical [32].

2.1. Synthesis and Characterization of Schiff Base Ligand (L). $1 \mathrm{~g}$ benzil was taken in $10 \mathrm{~mL}$ of $1: 1$ conc. $\mathrm{HNO}_{3}: \mathrm{H}_{2} \mathrm{SO}_{4}$ mixture and refluxed for 6 hours. A yellow product was obtained which was filtered and washed many times with distilled water. After drying, $0.5 \mathrm{~g}$ of the product was dissolved in $10 \mathrm{~mL}$ methanol. A freshly prepared solution of $\mathrm{SnCl}_{2}$ was added to this solution drop wise till the color became dark brown. The solvent was evaporated and the product was washed many times with distilled water and dried. The product was then dissolved in methanol and made basic by adding $\mathrm{NaOCH}_{3}$. Salicylaldehyde was added dropwise under stirring till the dark brown color of the solution became light brown. The solvent was evaporated under vacuum and product was washed many times with distilled water and dried. The product was further washed with n-hexane to remove any unreacted aldehyde present. The synthetic path for the ligand has been shown in Scheme 1.

Yield: 65\%. Elemental analysis: C 73.72\% (calc. 73.46), H 4.52 (calc. 4.40 ), N 8.35\% (calc. 8.16). ESI-MS m/z (rel. int. $\%) 687(\mathrm{M})^{+}$. FTIR $\left(\mathrm{KBr}\right.$ pallet, $\left.\mathrm{cm}^{-1}\right): 2852\left(v_{\mathrm{C}-\mathrm{H}}\right.$ of $\left.\mathrm{C}_{6} \mathrm{H}_{5}\right)$; $924.5 \mathrm{~cm}^{-1}, 880 \mathrm{~cm}^{-1}, 841 \mathrm{~cm}^{-1}, 817 \mathrm{~cm}^{-1} 765 \mathrm{~cm}^{-1}(\mathrm{C}-\mathrm{H}$ out of plan vibration for $\left.\mathrm{C}_{6} \mathrm{H}_{5}\right) ; 1352\left(v_{\mathrm{C}-\mathrm{O}}\right) ; 1680\left(v_{\mathrm{C}=\mathrm{O}}\right)$; $1597\left(v_{\mathrm{C}=\mathrm{N}}\right) ; 1381\left(v_{\mathrm{C}-\mathrm{N}}\right) ; 3430\left(v_{\mathrm{O}-\mathrm{H}}\right.$ alcoholic $) .{ }^{1} \mathrm{H}$ NMR $(300 \mathrm{MHz}) \mathrm{CDCl}_{3}: 8.876(\mathrm{~s}, \mathrm{HC}=\mathrm{N}), 8.393(\mathrm{~d}, \mathrm{Ar}-\mathrm{H}), 8.418$ $(\mathrm{s}, \mathrm{HC}=\mathrm{N}), 7.819(\mathrm{~d}, \mathrm{Ar}-\mathrm{H}), 7.587(\mathrm{~m}, \mathrm{Ar}-\mathrm{H}), 7.543(\mathrm{~m}$, Ar-H), 7.31 (m, Ar-H), 4.823 (s, -OH) (Figure 1).

2.2. Synthesis of the Complex. $0.1 \mathrm{~mol}$ of $\mathrm{L}$ was dissolved in $10 \mathrm{~mL}$ of methanol, and $0.2 \mathrm{~mol}$ of $\mathrm{Cu}$-acetate was added in small portions with continuous stirring followed by further stirring for 3 hours. Dark green product was obtained which was filtered and washed with distilled water. The compound was recrystallized from $\mathrm{CH}_{3} \mathrm{CN}$.

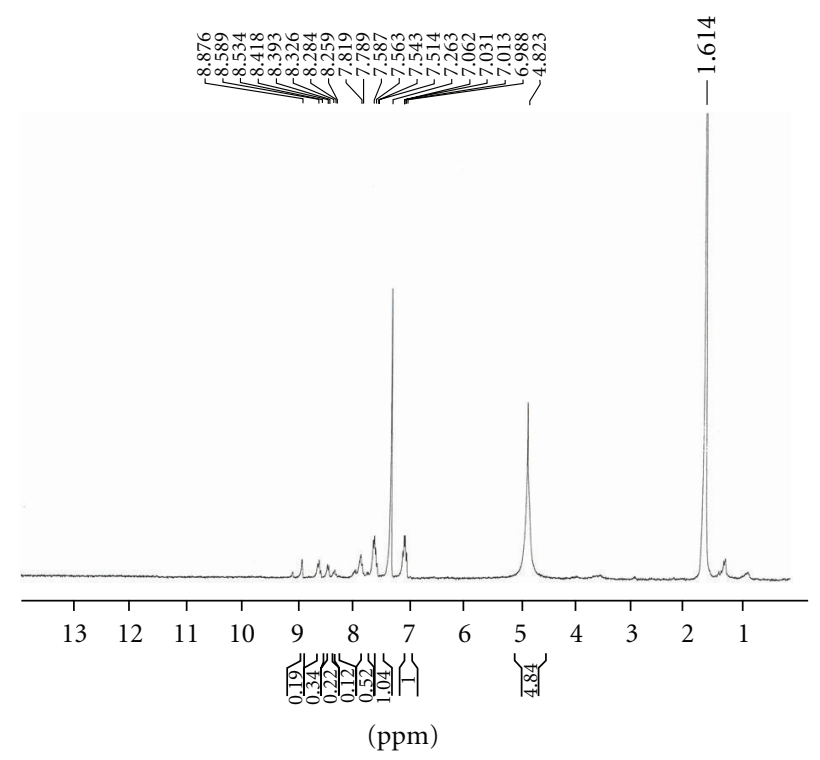

Figure 1: ${ }^{1} \mathrm{H}$ NMR spectra of $\mathrm{L}$ in $\mathrm{CDCl}_{3}$.

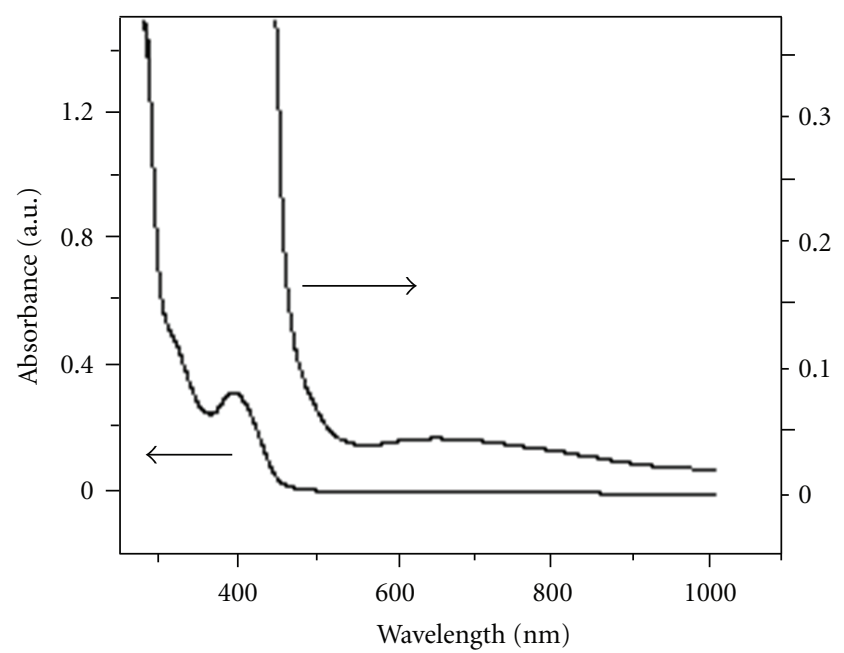

Figure 2: UV/Visible spectra of $\mathrm{Cu}(\mathrm{II})_{2} \cdot \mathrm{L} \cdot 2 \mathrm{H}_{2} \mathrm{O}$ in DMSO.

\section{Results and Discussion}

\subsection{Characterisation of the Bimetallic Copper(II) Complex}

3.1.1. UV/Visible and FTIR Spectroscopy. The uv/visible spectra of $\mathrm{L}$ showed two well-defined peaks at $213 \mathrm{~nm}$ and $323 \mathrm{~nm}$, due to $\pi-\pi^{*}$ and $n-\pi^{*}$, respectively, together with a shoulder at $400 \mathrm{~nm}$. Figure 2 shows the electronic spectra of the copper(II) complex in DMSO. When L formed complex with $\mathrm{Cu}(\mathrm{II})$, the peaks at $213 \mathrm{~nm}$ and $323 \mathrm{~nm}$ disappeared and the shoulder became a well-defined peak at $380 \mathrm{~nm}$. Binding to $\mathrm{Cu}$ (II) ion redistributed the electron densities of $\mathrm{L}$ and hence the first two peaks disappeared. The $380 \mathrm{~nm}$ peak should be due to ligand to metal charge transfer. Another peak at $700 \mathrm{~nm}$ was observed due to $\mathrm{d} \rightarrow \mathrm{d}$ transition originating at $\mathrm{Cu}(\mathrm{II})$. 

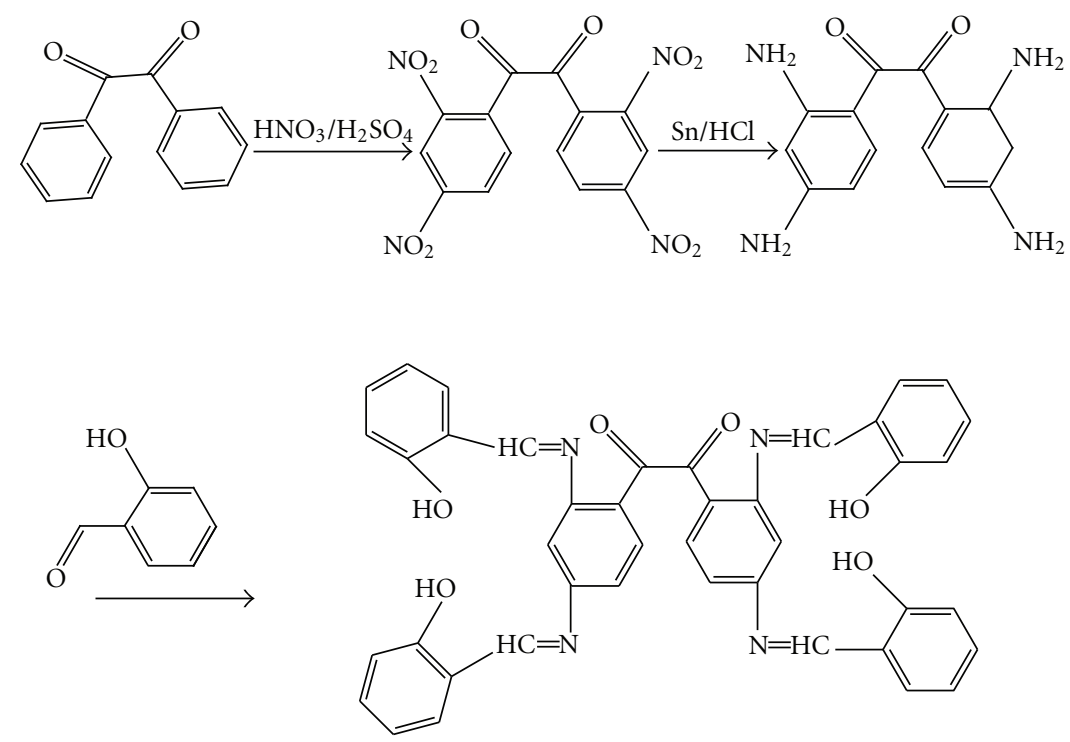

SCHEMe 1

FTIR spectra for the complex synthesized showed peaks at $2861 \mathrm{~cm}^{-1}\left(v_{\mathrm{C}-\mathrm{H}}\right.$ of $\left.\mathrm{C}_{6} \mathrm{H}_{5}\right) ; 772.8 \mathrm{~cm}^{-1}, 718.9 \mathrm{~cm}^{-1}$ $\left(\mathrm{C}-\mathrm{H}\right.$ out of plan vibration for $\left.\mathrm{C}_{6} \mathrm{H}_{5}\right) ; 1616.5 \mathrm{~cm}^{-1}\left(v_{\mathrm{C}=\mathrm{O}}\right)$; $1538.1 \mathrm{~cm}^{-1}\left(v_{\mathrm{C}=\mathrm{N}}\right) ; \quad 1391 \mathrm{~cm}^{-1}\left(v_{\mathrm{C}-\mathrm{N}}\right) ; 1349.3 \mathrm{~cm}^{-1}$ $\left(v_{\mathrm{C}-\mathrm{N}}\right) ; \quad 3430.9 \mathrm{~cm}^{-1} \quad\left(v_{\mathrm{O}-\mathrm{H}}\right.$ coordinated $\left.\mathrm{H}_{2} \mathrm{O}\right)$. The stretching frequency due to $v_{\mathrm{C}=\mathrm{O}}$ has decreased to $1616.5 \mathrm{~cm}^{-1}$ in the complex from $1680 \mathrm{~cm}^{-1}$ in the ligand. This indicates possibility of formation of $\mathrm{H}$ bonding between coordinated water molecule and the carbonyl groups.

3.1.2. Magnetic Moment Measurements. The magnetic moment value was measured to be $2.199 \mathrm{BM}$ which was much higher than the single electron value of 1.74 BM. This magnetic moment value can be explained by considering that the complex formed is a bimetallic $\mathrm{Cu}(\mathrm{II})$ one. Because of exchanged couple phenomena, the observed magnetic moment is smaller than the total magnetic moment due to two single $\mathrm{Cu}(\mathrm{II})$ ions, that is, $1.74 \mathrm{BM} \times 2=3.48 \mathrm{BM}$.

3.1.3. EPR Studies of the Complex. The X-band EPR spectra of the complex was recorded as the polycrystalline samples at room temperature (Figure 3). The $g_{\text {iso }}$ value and geometric parameter $G$, that is, the measurement of exchange interaction between the copper centers were evaluated by using the following expression [31]:

$$
\begin{gathered}
g_{\text {iso }}=\frac{\left(g_{l l}+2 g_{\perp}\right)}{3}, \\
G=\frac{\left(g_{l l}-2.0023\right)}{\left(g_{\perp}-2.0023\right)}=\frac{4 K_{l l}^{2} \Delta E_{x z}}{k_{\perp}^{2} \Delta E_{x y}} .
\end{gathered}
$$

The calculated value of $g$ tensor parameter was $g_{l l}=2.24$ and $g_{\perp}=2.11$. Hence $g_{l l}>g_{\perp}>2.0023$ which reveals that $d_{x 2-y 2}$ is the ground state [30]. The value of $G$ was calculated to be 2.207 which means $G$ is less than 4 indicating effective interaction between the copper centers [32].
3.1.4. Thermogravimetric Analysis. Thermogravimetric (TG) weight loss curves and the corresponding differential thermogravimetric (DTG) curves for the complex are shown in Figure 4. The complex showed two well-defined steps at $160^{\circ} \mathrm{C}$ and $290^{\circ} \mathrm{C}$ together with another steps at $350^{\circ} \mathrm{C}$. The loss in weight in the first step is $4.02 \%$ which should be due to the two co-ordinated water molecules (calculated weight loss was $4.28 \%$ ). The second, and third weight losses are $65.95 \%$ and $6.58 \%$, respectively, totaling $72.53 \%$. This large weight drop can be explained by considering that the residue is a $1: 1$ mixture of $\mathrm{Cu}_{2} \mathrm{O}$ and $\mathrm{CuO}$ (calculated weight loss $72.51 \%$ ).

Based on various spectroscopic and magnetic studies together with the TG analysis results, the structure of the complex has been confirmed to the one shown in Scheme 2.

3.1.5. Electrochemical Study of the Complex. Figure 5 shows the cyclic voltammogram of $\mathrm{Cu}(\mathrm{II}) \cdot \mathrm{L} \cdot 2 \mathrm{H}_{2} \mathrm{O}$ in $\mathrm{CH}_{3} \mathrm{CN}$ using platinum disc as working electrode and $\mathrm{Ag}-\mathrm{AgCl}$ as the reference. The cyclic voltammetric profile is of quasi reversible one with the redox potential value $+0.105 \mathrm{~V} \pm 0.005 \mathrm{~V}$ with peak potential difference $\Delta E=0.228 \mathrm{~V}$. This redox potential is due to $\mathrm{Cu}(\mathrm{II}) / \mathrm{Cu}(\mathrm{I})$ redox couple. The ratio of cathodic to anodic current is found to be 0.949 . The redox potential value was further confirmed by square wave voltammogram (not shown). Observation of only one redox couple in the cyclic voltammogram or square wave voltammogram confirms that both the $\mathrm{Cu}(\mathrm{II})$ ions are in identical coordination environment.

The plot of cathodic and anodic currents versus square root of scan rate was found to be linear. This linearity in redox currents against square root of scan rate indicates the redox process is diffusion controlled. Double potential step chronocoulometry was done for the complex in DMSO. The plot of charge $(Q)$ versus square root of time $\left(t^{1 / 2}\right)$ was gradual, and no sharp decrease was observed. This confirms 


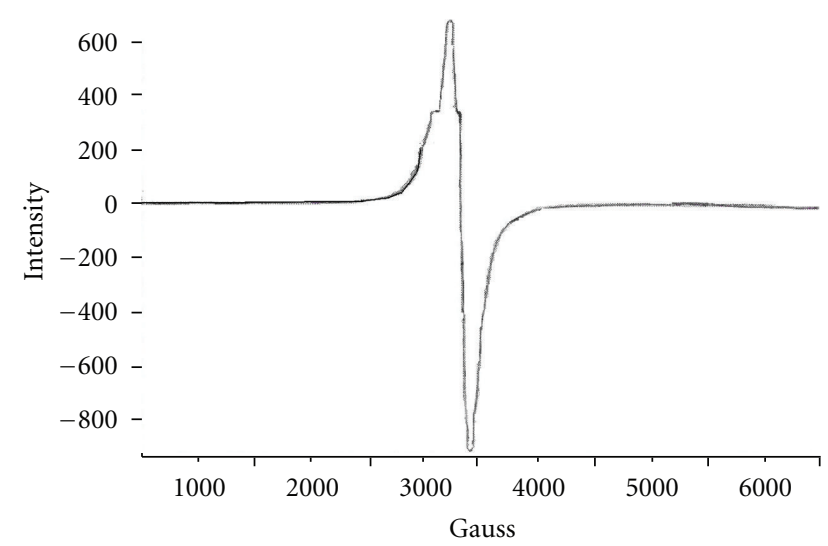

FIgURE 3: X-band EPR spectra of $\mathrm{Cu}(\mathrm{II})_{2} \cdot \mathrm{L} \cdot 2 \mathrm{H}_{2} \mathrm{O}$ in solid state.

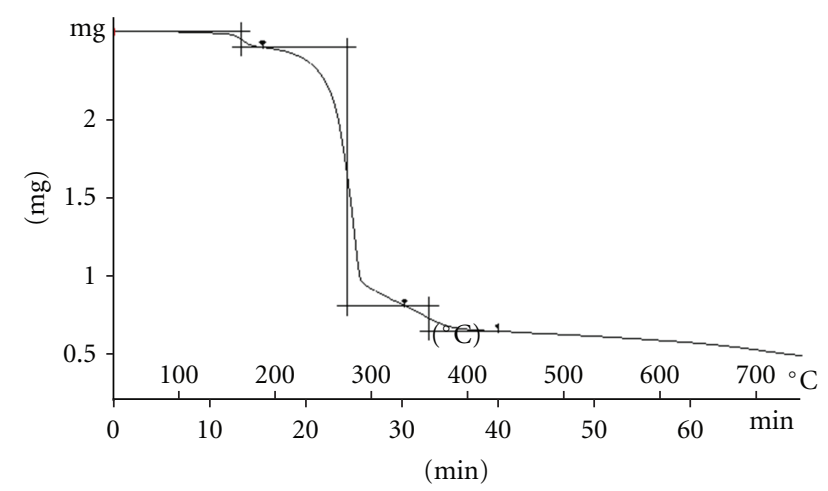

Figure 4: TGA curve of $\mathrm{Cu}(\mathrm{II})_{2} \cdot \mathrm{L} \cdot 2 \mathrm{H}_{2} \mathrm{O}$.

that the complex was not adsorbed onto the electrode surface, and the redox process is diffusion controlled.

3.1.6. Superoxide Dismutase (SOD) Activity of the Complex. The SOD activity of the copper complex has been studied by the method of NBT reduction using $\mathrm{KO}_{2}{ }^{-\bullet}$ as the source of superoxide radical [32]. The blue color developed due to the formation of dye was measured immediately at $560 \mathrm{~nm}$ against an appropriate blank. One unit of SOD activity $\left(\mathrm{IC}_{50}\right.$ value) was defined as the test substance required for $50 \%$ inhibition of NBT reduction by the superoxide anion [27]. A linear relation was obtained between the concentration of the copper complex and the inhibition of the superoxide ion. The $100 \%$ of superoxide activity corresponds to an assay performed in the absence of complex. In order to determine the concentration of the complex required to yield $50 \%$ inhibition of the reaction, we plotted the percentage of inhibition against the metal complex concentration. A linear relation was obtained between the concentration of the copper complex and the inhibition of the superoxide ion and from this plot $\mathrm{IC}_{50}$ value could be determined. The obtained value was $0.150 \mathrm{mM}$ which was lower than the $\mathrm{IC}_{50}$ value reported $[25,27]$. The $\mathrm{IC}_{50}$ value of the native enzyme is $0.72 \mu \mathrm{M}$.

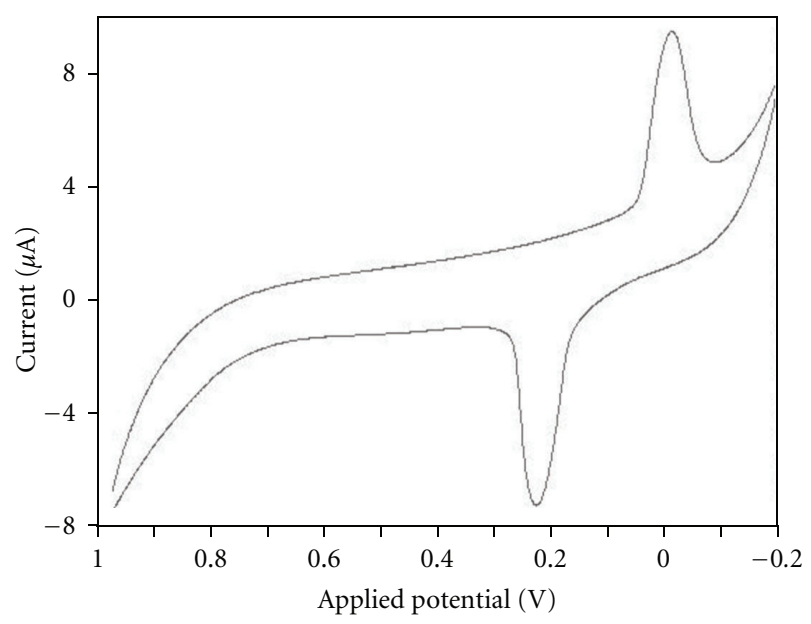

Figure 5: Cyclic voltammogram of $\mathrm{Cu}(\mathrm{II})_{2} \cdot \mathrm{L} \cdot 2 \mathrm{H}_{2} \mathrm{O}$ in DMSO. Working electrode: $\mathrm{Pt}$ disc, reference electrode: $\mathrm{Ag}-\mathrm{AgCl}$, supporting electrolyte: TBAP.

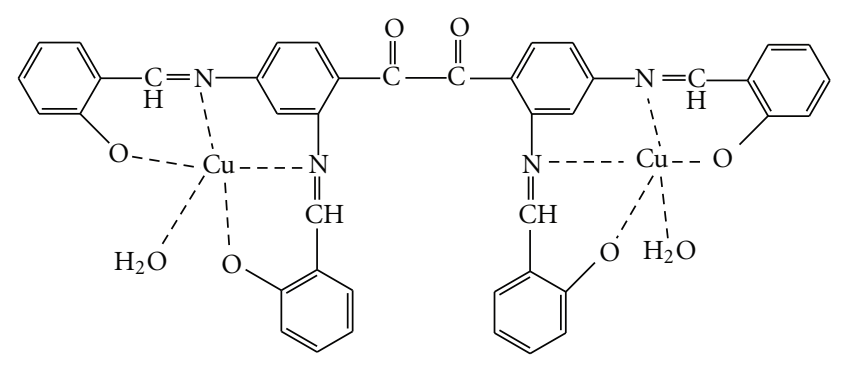

SCHEME 2

\section{Conclusions}

A new Schiff base ligand system obtained from benzil by firstly introducing nitro groups which were reduced to amine and secondly allowing condensation between the amine and salicylaldehyde has been synthesized and characterized. The ligand binds to two $\mathrm{Cu}(\mathrm{II})$ ions giving a new bimetallic $\mathrm{Cu}(\mathrm{II})$ complex which shows efficient superoxide dismutase activity.

\section{Acknowledgments}

UGC, New Delhi and DST, New Delhi are acknowledged for financial support to the department. B. Sarma thanks UGC, New Delhi for a fellowship under RFSMS.

\section{References}

[1] C. D. Berdanier, J. L. Goff, and S. S. Gropper, Advanced Nutrition and Human Metabolism, Words Worth/Thompson Learning, Belmont, Calif, USA, 3rd edition, 1999.

[2] A. S. Brill, R. B. Martin, and R. J. P. Williams, Electronic Aspects of Biochemistry, Academic Press, New York, NY, USA, 1964.

[3] E. Frieden, S. Osaki, and H. Kobayashi, "Copper proteins and oxygen. Correlations between structure and function of the copper oxidases," Journal of General Physiology, vol. 49, no. 1, pp. 213-252, 1965. 
[4] R. M. S. Pereira, N. E. D. Andrades, N. Paulino et al., "Synthesis and characterization of a metal complex containing naringin and $\mathrm{Cu}$, and its antioxidant, antimicrobial, antiinflammatory and tumor cell cytotoxicity," Molecules, vol. 12, no. 7, pp. 1352-1366, 2007.

[5] I. B. Afanasev, E. A. Ostrskhovitchm, E. V. M. Chik, C. A. Ibraginova, and L. G. Korkina, "Does the antitumor cyclopropylpyrroloindole antibiotic CC-1065 cross-link DNA in tumor cells?” Biochemical Pharmacology, vol. 61, no. 1, pp. 67-72, 2001.

[6] M. Mohan, N. K. Gupta, and M. Kumar, "Synthesis, magnetic and electrochemical properties of binuclear copper(II) complexes of pyridoxal hydrazones," Inorganica Chimica Acta, vol. 197, no. 1, pp. 39-40, 1992.

[7] S. K. Mandal and K. Nag, "Dinuclear metal complexes. Part 3. Preparation and properties of hydroxo-bridged dicopper(II) complexes," Journal of the Chemical Society, Dalton Transactions, no. 10, pp. 2141-2149, 1984.

[8] P. K. Coughlin and S. J. Lipard, "A monohydroxobridged, strongly antiferromagnetically coupled dicopper(II) center in a binucleating macrocycle. Comparisons with binuclear copper sites in biology," Journal of the American Chemical Society, vol. 103, no. 11, pp. 3228-3228, 1981.

[9] R. N. Patel, "Magnetic, epr and SOD studies of some $\mathrm{Cu}^{\mathrm{II}}$ $\mathrm{Cu}^{\mathrm{II}}, \mathrm{Cu}^{\mathrm{II}}-\mathrm{Ni}^{\mathrm{II}}$ and $\mathrm{Cu}^{\mathrm{II}}-\mathrm{Zn}^{\mathrm{II}}$ imidazolate bridged complexes," Spectrochimica Acta Part A, vol. 59, no. 4, pp. 713-721, 2003.

[10] R. R. Gagne, R. P. Kreh, and J. A. Dodge, "Unusual structural and reactivity types for copper(I). Synthesis and structural and redox properties of binuclear copper(I) complexes which are probably three coordinate in solution and experience intermolecular metal-metal interactions in the solid state," Journal of the American Chemical Society, vol. 101, no. 23, pp. 6917-6927, 1979.

[11] E. I. Solomon, "Electronic and geometric structure-function correlations of the coupled binuclear copper active site," Pure and Applied Chemistry, vol. 55, no. 7, pp. 1069-1088, 1983.

[12] R. N. Patel, N. Singh, K. K. Shukla, V. L. N. Gundla, and U. K. Chauhan, "Synthesis, spectra and biomimetic properties of copper(II)-copper(II) and copper(II)-zinc(II) binuclear complexes with $\mathrm{CuN}_{5}$ chromophores," Spectrochimica Acta Part A, vol. 61, no. 11-12, pp. 2603-2610, 2005.

[13] D. R. McMillin and K. M. McNett, "Photoprocesses of copper complexes that bind to DNA," Chemical Reviews, vol. 98, no. 3, pp. 1201-1219, 1998.

[14] K. E. Erkkila, D. T. Odom, and J. K. Barton, "Recognition and reaction of metallointercalators with DNA," Chemical Reviews, vol. 99, no. 9, pp. 2777-2795, 1999.

[15] A. S. Gardberg, P. E. Daon, B. M. Hoffman, and J. A. Ibers, "Singly and doubly oxidized phthalocyanine (pc) Rings: $\left[\mathrm{Cu}(\mathrm{pc})\left(\mathrm{ReO}_{4}\right)\right]$ and $\left[\mathrm{Cu}(\mathrm{pc})\left(\mathrm{ReO}_{4}\right)_{2}\right]$," Angewandte Chemie International Edition, vol. 40, no. 1, pp. 244-246, 2001.

[16] J. K. Swearingen and D. X. West, "Structural and spectral studies of di-2-pyridyl ketone N(4)-methyl- and N(4)dimethylthiosemicarbazone and their metal complexes," Transition Metal Chemistry, vol. 26, no. 3, pp. 252-260, 2001.

[17] G. Wilkinson, R. D. Gillard, and J. A. Mc Cleverty, Comprehensive Coordination Chemistry, vol. 2, Elsevier, Oxford, UK, 1987.

[18] T. C. Pederson and S. D. Aust, "The role of superoxide and singlet oxygen in lipid peroxidation promoted by xanthine oxidase," Biochemical and Biophysical Research Communications, vol. 52, no. 3, pp. 1071-1078, 1973.
[19] Y. Mizushima, R. Igarshi, C. G. Wermuth, N. Koga, H. Kinig, and B. W. Metcalf, Medicinal Chemistry for the 21st Century, Black-Well Scientific Publications, Oxford, UK, 1992.

[20] G. Tabbi Nauser T, W. H. Koppenol, and J. Reedijk, "A pulse radiolysis study of an imidazolato-bridged asymmetric dicopper(II) complex: a structural and functional mimic of superoxide dismutase," European Journal of Inorganic Chemistry, no. 12, pp. 1939-1943, 1998.

[21] B. Halliwell and J. M. C. Gutteridge, Free Radicals in Biology and Medicine, Clarendon Press, Oxford, UK, 2nd edition, 1989.

[22] A. E. Liczmanski, H.-J. Hartmann, and U. Weser, "Neutralization of superoxide dismutase defficiency effects by environment changes in yeast Saccharomyces cerevisiae. III. Copper complexes with superoxide dismutase activity," Bulletin of the Polish Academy of Sciences, vol. 42, no. 4, pp. 291-297, 1994.

[23] A.-M. Liu, R.-G. Xiong, and X.-Z. You, "A novel, more vivid $\mathrm{Cu}_{2} \mathrm{Zn}_{2}$ SOD model: crystal structure and some properties of the Schiff base copper(II) complex: $[\mathrm{Cu}(\mathrm{appn})]\left(\mathrm{ClO}_{4}\right)_{2} \cdot \mathrm{H}_{2} \mathrm{O}$," Polyhedron, vol. 16, no. 1, pp. 119-123, 1997.

[24] G. Tabbi, W. L. Driessen, J. Reedijk, R. P. Bonomo, N. Veldman, and A. L. Spek, "High superoxide dismutase activity of a novel, intramolecularly imidazolato-bridged asymmetric dicopper(II) species. Design, synthesis, structure, and magnetism of copper(II) complexes with a mixed pyrazole-imidazole donor set," Inorganic Chemistry, vol. 36, no. 6, pp. 1168-1175, 1997.

[25] R. G. Bhirud and T. S. Srivastava, "Superoxide dismutase activity of $\mathrm{Cu}(\mathrm{II})_{2}$ (aspirinate) ${ }_{4}$ and its adducts with nitrogen and oxygen donors," Inorganica Chimica Acta, vol. 173, no. 1, pp. 121-125, 1990.

[26] A. Barik, B. Mishra, A. Kunwar et al., "Comparative study of copper(II)-curcumin complexes as superoxide dismutase mimics and free radical scavengers," European Journal of Medicinal Chemistry, vol. 42, no. 4, pp. 431-439, 2007.

[27] J. Patole, S. Dutta, S. Padhye, and E. Sinn, "Tuning up superoxide dismutase activity of copper complex of salicylaldehyde semicarbazone by heterocyclic bases pyridine and N-methyl imidazole," Inorganica Chimica Acta, vol. 318, no. 1-2, pp. 207-211, 2001.

[28] T. Suksrichavalit, S. Prachayasittikul, T. Piacham, C. Isarankura-Na-Ayudhya, C. Nantasenamat, and V. Prachayasittikul, "Copper complexes of nicotinic-aromatic carboxylic acids as superoxide dismutase mimetics," Molecules, vol. 13, no. 12, pp. 3040-3056, 2008.

[29] T. Suksrichavalit, S. Prachayasittikul, C. Nantasenamat, C. Isarankura-Na-Ayudhya, and V. Prachayasittikul, "Copper complexes of pyridine derivatives with superoxide scavenging and antimicrobial activities," European Journal of Medicinal Chemistry, vol. 44, no. 8, pp. 3259-3265, 2009.

[30] S. Prachayasittikul, A. Worachartcheewan, R. Pingaew et al., "Metal complexes of uracil derivatives with cytotoxicity and superoxide scavenging activity," Letters in Drug Design \& Discovery, vol. 9, no. 3, pp. 282-287, 2012.

[31] J. Rajbongshi, D. K. Das, and S. Mazumdar, "Direct electrochemistry of dinuclear $\mathrm{Cu}_{\mathrm{A}}$ fragment from cytochrome $\mathrm{c}$ oxidase of Thermus thermophilus at surfactant modified glassy carbon electrode," Electrochimica Acta, vol. 55, no. 13, pp. 4174-4179, 2010.

[32] S. Chandra, D. Jain, and A. K. Sharma, "EPR, mass, electronic, IR spectroscopic and thermal studies of bimetallic copper(II) complexes with tetradentate ligand, 1,4-diformyl piperazine bis(carbohydrazone)," Spectrochimica Acta Part A, vol. 71, no. 5, pp. 1712-1719, 2009. 

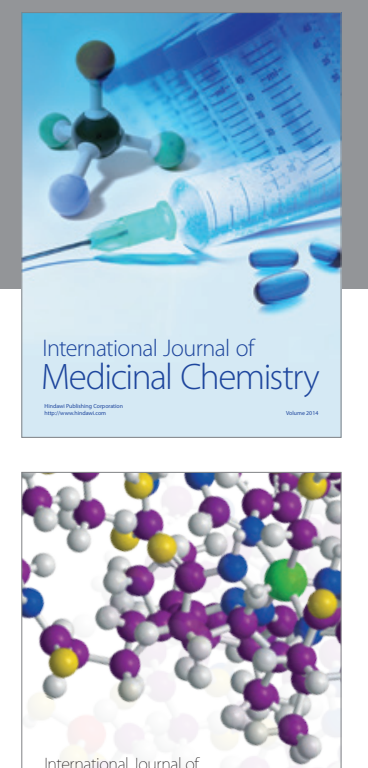

\section{Carbohydrate} Chemistry

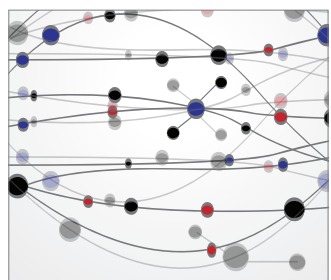

The Scientific World Journal
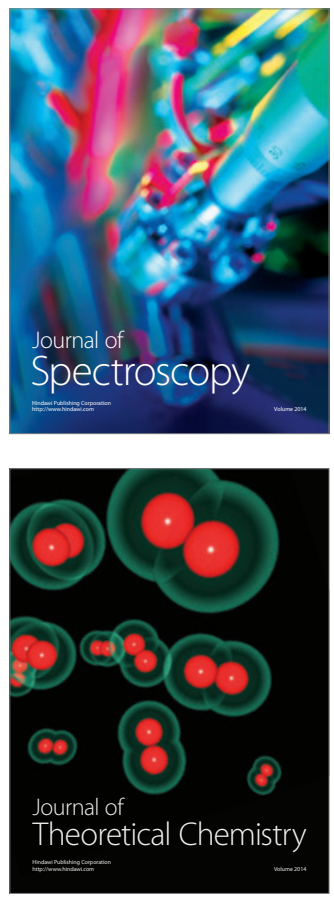
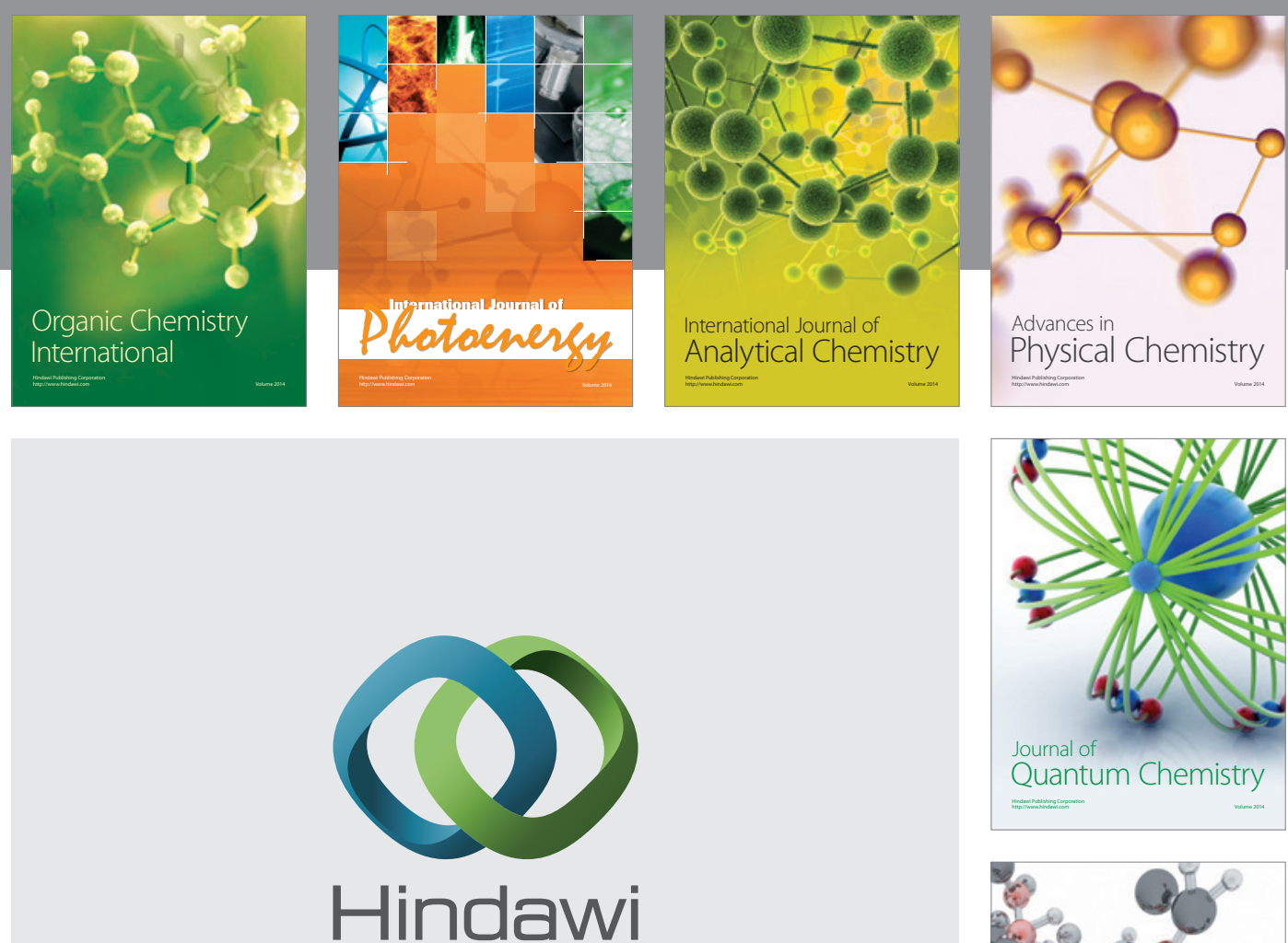

Submit your manuscripts at

http://www.hindawi.com

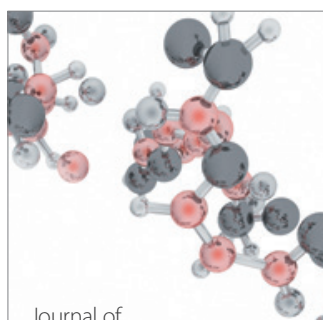

Analytical Methods

in Chemistry

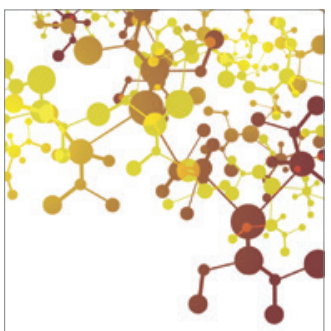

Journal of

Applied Chemistry

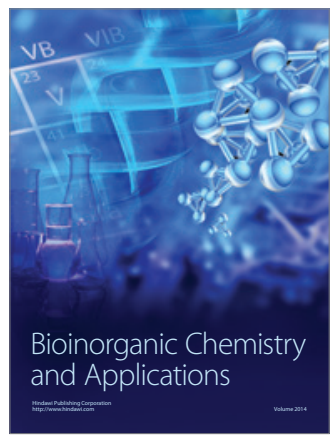

Inorganic Chemistry
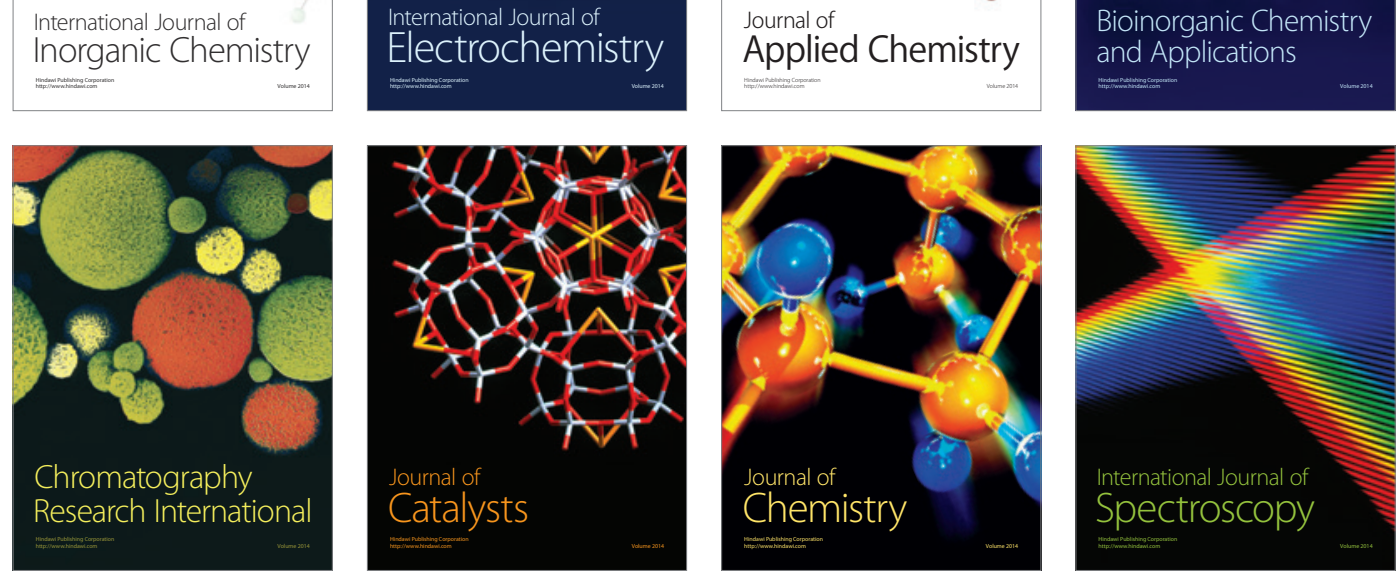